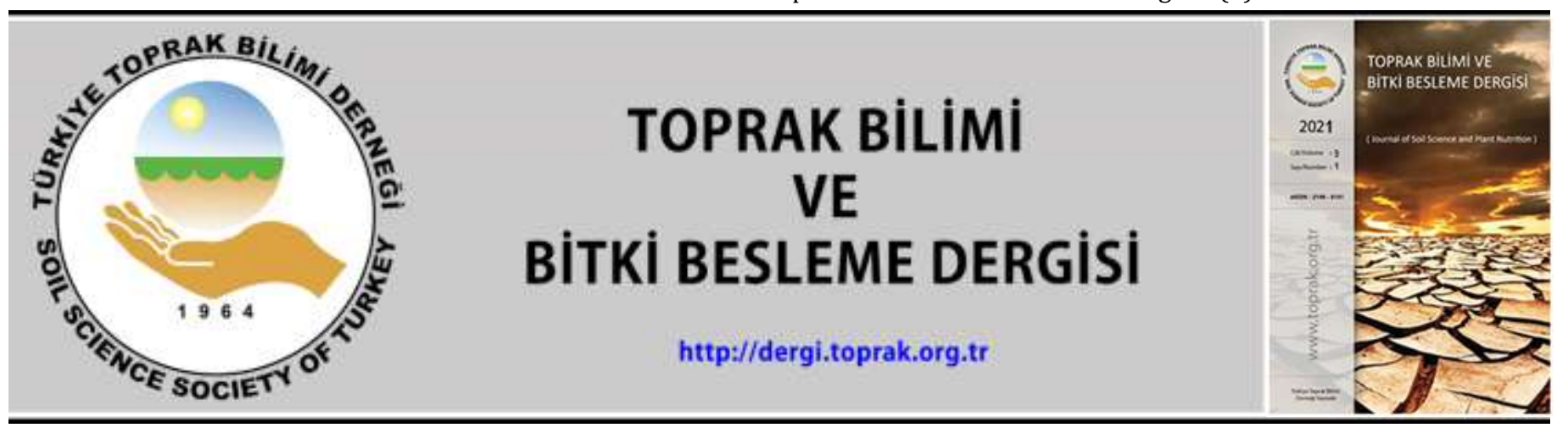

\title{
Güney - Kazakistan'da sulu tarım yapılan toprakların bazı fiziksel özellikleri ve geçirgenlikleri
}

${ }^{\text {Maussymzhan Beisenbayeva }}{ }^{1}$, $\odot$ Sydyk Dosymbek ${ }^{2}$, Aigul Zhapparova $^{1}$, Kadisha Toktibayeva ${ }^{3}, \odot$ Gulnur Utenbayeva ${ }^{1}, \odot$ Bolat Murzabayev $^{2}$, Zhainagul Yertayeva*1

\author{
${ }^{1}$ Kazakh National Agricultural University, Almaty, Kazakhstan \\ 2Southwest Research Institute of Animal Husbandry and Crop Production, Shymkent, Kazakhstan \\ ${ }^{3}$ M. Auezov South Kazakhstan State University, Shymkent, Kazakhstan
}

\begin{abstract}
Özet
$\mathrm{Bu}$ çalışma, Kazakistan'ın güney bölgelerindeki sulanan arazilerin bazı fiziksel özelliklerini ve geçirgenlik durumlarını ele almaktadır. Mevcut iklim koşulları altında ve küresel iklim değisşiklikleri ile bağlantılı olarak, sulama suyu açığı her yıl artmaktadır. Kültür bitkilerinin ve toprak mikroorganizmalarının gelişim koşulları büyük ölçüde suya bağlı olduğundan, sulama rejimi ve su tasarrufu teknolojisi geliştirilirken, sulu tarım yapılan arazi koşullarında toprakların fiziksel özelliklerinin de bilinmesi önemlidir. Toprak işleme yöntemleri, bitkilerin sulanması ve sulama sıklı̆̆ı gibi pek çok faktör, toprakların fiziksel özelliklerinin etkisi altındadır. Bu çalışmanın yürütüldügü arazinin 0-30 cm'sinde \%1,38 organik madde içeren ve bitkiye yarayışlı $\mathrm{N}$ ve $\mathrm{P}$ içeriği düşük, $\mathrm{K}$ içeriği ise orta seviyede olan sierozem topraklar pek çok bitkinin yetiştirilmesi için uygundur. Deneme arazisinde profil boyunca alınan toprak örneklerinde higroskopik sabite değerleri \%4,55 - \%4,71 arasında, hacim ağırlı̆g 1,46 - 1,58 g/ $\mathrm{cm}^{3} \mathrm{arasında,} \mathrm{toplam}$ porozite \%41,5 - \%42,7 arasında ve toprağın en düşük gravimetrik nem içeriğinin ise \%21,4 - \%22,6 arasında değiştiği saptanmıștır. Bununla beraber, topraklara $100 \mathrm{~mm}$ seviyesinde uygulanacak sulama suyunun ancak 24 saat'ten daha fazla bir süre içerisinde (24,6 - 27,0 saat) infiltre olabileceği saptanmıștır.
\end{abstract}

Anahtar Kelimeler: Hacim ağırlığı, özgül ağırlık, porozite, higroskopik su, infiltrasyon.

\section{Some physical properties and permeability of irrigated soils in South - Kazakhstan}

\begin{abstract}
This study reveals that some physical properties and permeability of irrigated lands in the Southern Regions of Kazakhstan. The deficiency of irrigation water increases every year under the current climate conditions and in connection with global climate change. It is important to know the physical properties of the soils in irrigated land conditions while developing the irrigation regime and water saving technology because the growth conditions of cultivated plants and soil microorganisms are largely dependent on water. Methods of soil tillage, terms and norms of irrigating cultivated crops, and many other factors are under the effect of soil physical properties. Sierozem soils containing $1.38 \%$ organic matter, low N and P contents and medium K content in 0 $30 \mathrm{~cm}$ of the land where this study was conducted, are suitable for the cultivation of many plants. In the soil samples taken along the profile in the experimental area, the hygroscopic moisture constants are between $4.55 \%-4.71 \%$, the bulk density is between 1.46 $1.58 \mathrm{~g} / \mathrm{cm}^{3}$, the total porosity is between $41.5 \%-42.7 \%$ and the soil lower gravimetric moisture content varied between $21.4 \%$ and $22.6 \%$. Also, it has been found that $100 \mathrm{~mm}$ irrigation water applied to the soil can infiltrate more than $24 \mathrm{~h}$ (24.6 - $27.0 \mathrm{hours})$.
\end{abstract}

Keywords: Bulk density, particle density, porosity, hygroscopic water, infiltration.

(C) 2021 Türkiye Toprak Bilimi Derneği. Her Hakkı Saklıdır

\section{Giriş}

Kazakistan'ın nehirleri ve nehir kenarlarındaki su kaynakları üzerine yeterince ve detaylı çok sayıda araştırma yapılmıştır. Kazakistan tarım toprakları esas olarak nehirlerin bulunduğu havzaların aşağı kısımlarında yer almaktadır. Bu nedenle komşu bölgelerden gelen su miktarı giderek azalmaktadır. Yapılan

\footnotetext{
* Sorumlu yazar:

Tel. $\quad$ : $\quad+77025050404$

E-posta : jain_04_04@mail.ru
}

Geliș Tarihi

Kabul Tarihi
06 Mayıs 2021

25 Mayıs 2021
e-ISSN : 2146-8141

DOI : $10.33409 /$ tbbbd.933719 
çalışmalar ve analizler ile Kazakistan topraklarına sınıraşan nehirler yoluyla giren su kaynaklarının, komşu ülkelerde ekonomik sektörler geliştikçe azalma eğiliminde olduğunu ortaya koymaktadır. Dolayısıyla, 1960 yılında Kazakistan'ın su kaynakları yıllık 114,96 km³ iken, (Zaurbek ve Makhanov, 2003), bu miktar 2000 yılında 100,5 km³ (Dmitriev, 2004)'e düşmüştür. Kazakistan topraklarında yılda 3,2 km³ su oluşmaktadır (Burlibayev ve ark. 2001). 2000 yılı Syrdarya havzasında ekonomik sektörler tarafından su tüketimi ise 8,61 $\mathrm{km}^{3}$ (Anonymus, 2004) olmuştur. 2010 ve 2020 yllı verileri ise 2000 yılı verilerine eşittir. Hem Güney Kazakistan'da hem de Kızlorda bölgelerinde sanayi sektörlerinin suya olan taleplerinin büyük olasılıkla artması beklenmektedir. Bu durumda, su üretim miktarını artırma imkanı olmayan Kazakistan'ın komşu devletlerinde su kaynaklarının akılcı bir şekilde kullanımına yönelik sorunlarını çözmesi gerekmektedir. Yapılan araştırmalara göre, Kazakistan'da sulamaya uygun arazi miktarı 60 milyon hektarın üzerinde olmasına karşın, toplam 7,4 milyon hektar tarımsal alan mevcut su kaynakları ile sulanabilmektedir. Bununla birlikte, sınıraşan nehirlerden su girişinin azalması ve nehir havzalarındaki doğal komplekslerin korunmasıyla, sulanan alanlar gelecekte azalacaktır (Evniev, 2005). Bu nedenle, genel olarak azalan su temini ve artan su açığı nedeniyle, sulu tarımda suyun akılcı kullanımının sağlanması, ıslah faaliyetlerinin yürütülmesinde ve ürün sulama rejimlerinin geliștirilmesinde su yönetimi uygulamaları son yılların önemli konularından birisi haline gelmektedir.

Son yıllarda, mevcut piyasa koşullarında, Kazakistan'ın hem iç pazarında hem de dış pazarında, tek yıllık bir bitki olan soya fasulyesi ürünlerine olan talep her geçen yıl giderek artmaktadır. Soya fasulyesi, subtropikal kökenli, sıcağı, ışığı ve suyu seven bir bitkidir. Son 20 yılda dünyada soya fasulyesi üretimi 2,16 kat artarken, ürünlerin ekim alanları 1,6 kat ürün verimi de 1,35 kat artış göstermiştir. Soya fasülyesinin dünyadaki tüm ekim alanlarının \% 90'ının ABD, Brezilya, Arjantin, Çin ve Hindistan'da yoğunlaştığı görülmektedir (Tour ve Zagorulko, 1994). Soya fasulyesinin endüstriyel kullanımının genişletilmesi ve soya proteinli ürünlerin gida amaçlı kullanımı, mevcut protein eksikliklerini azaltmada, ortadan kaldırmada ve nüfusun beslenme yapısını iyileştirmede en etkili yollarından birisidir. Bu amaçla soya fasulyesi, tereyağı, margarin, soya peyniri, süt, un, şekerlemeler, konserve yiyeceklerin üretilmesi gibi çeşitli amaçlar için kullanılmaktadır. Bununla beraber, \% 47'ye kadar protein içeren soya fasulyesinin yağı da büyük önem taşımaktadır. Bu nedenle, soya fasulyesi, yüksek besin değeri ve protein içeriği dikkate alındığında ise UNESCO tarafından stratejik bir kültür bitkisi olarak tanımlanmaktadır (Didorenko ve Karyagin, 2006). Güney Kazakistan'ın sıcak ve kurak yaz aylarında yüksek soya verimi elde etmenin en temel yollarından birisi de kuşkusuz toprağın optimum seviyede su içermesidir. Ancak, özellikle yaz aylarında veya kritik dönemlerinde sulama suyu miktarı çoğunlukla yeterli değildir ve soya fasulyesinin ürün veriminde bu durum önemli düşüşlere neden olmaktadır. Bu çalışmada, Güney - Kazakistan'da sulu tarım yapılan arazilerin bazı fiziksel toprak özellikleri ve geçirgenlik durumları araştırılmıştır.

\section{Materyal ve Yöntem}

Deneme 2018-2019 yıllarında Güney-Batı Hayvancılık ve Bitkisel Üretim Araştırma Enstitüsü'ne ait Tarım ve Bitkisel Üretim deneme istasyonunda yürütülmüştür. Bu deneme arazisi toprakları Eski Amerikan Toprak Sınıflama sistemine göre "Sierozem" olarak sınıflandırılabilen tın bünyeli topraklardır. Tarım arazileri Güney - Kazakistan'daki Talas Alatau'nun batısındaki, Tanrı dağlarının dağ eteklerinde bulunmakta olup, 200-350 m'den 900-1000 m yüksekliğe kadar dikey bir hat boyunca dağlım göstermektedir. İklim faktörleri ve bitki örtüsüne göre farklıkların oluştuğu toprakların organik madde içeriği, morfolojik özellikler ve diğer kimyasal özelliklere göre, bu alandaki sierozemler, koyu sierozemler (gri-kahverengi karbonatlı), siradan sierozemler ve hafif sierozemler şeklinde 3 ayrı farklı alt türe ayrılmaktadır.

Tanrı dağlarının eteklerindeki deneme arazisi, okyanus ve denizlerden uzak konumu, yazları sıcak olan sert bir karasal iklime sahiptir. Deneme arazisinde en sıcak ay $26,1^{\circ} \mathrm{C}$ ortalama sicaklık ile Temmuz ayında, en soğuk ay ise $2,6^{\circ} \mathrm{C}$ ile Ocak ayıdır. $10^{\circ} \mathrm{C}$ 'nin üzerindeki ortalama hava sıcaklığı, Nisan ayının ikinci yarısında başlamakta ve Eylül ayı sonuna değin sürmektedir. Don riski 210 ila 234 gün arasında değişmekle birlikte ortalama 222 gündür. Deneme arazisinin bulunduğu bölge, Güney Kazakistan'da Tanrı dağlarının eteklerindeki düzlükler ile Türkistan ve Turan ovalarını da içermekte olup, önemli bir tarımsal potansiyele sahiptir.

Deneme arazisi topraklarının organik madde, alınabilir $\mathrm{NO}_{3}, \mathrm{P}_{2} \mathrm{O}_{5}$ ve $\mathrm{K}_{2} \mathrm{O}$ içerikleri ile özgül ağırlık, hacim ağırlığı, toplam porozite, higroskopik sabite ve en düşük nem içeriği değerleri Black (1965) tarafından bildirilen yöntemlere göre belirlenmiştir. 


\section{Bulgular ve Tartışma}

Deneme arazisinin farklı derinliklerinden alınan toprak örneklerinde yaplan alınabilir besin maddesi içerikleri ile toprakların organik madde $(\mathrm{OM})$ içerikleri Çizelge 1'de verilmiştir. Deneme arazisinin alınabilir N ve P içeriği düşük, K içeriği ise orta seviyede olup toprak hafif alkalen reaksiyon göstermektedir $(\mathrm{pH}, 7,8)$. Genellikle yaygın Sierozem toprakların çoğu sulama koşulları altında birçok bitkinin yetiştirilmesi için uygundur. Alınabilir N, P ve K içerikleri ile $\mathrm{pH}$ ve humus içeriğine göre, deneme alanındaki sierozem topraklar pek çok bitkinin yetişmesi için uygundur.

Çizelge 1. Deneme arazisindeki toprakların alınabilir N, P ve K içerikleri ile organik madde kapsamı

\begin{tabular}{ccccc}
\hline \multirow{2}{*}{ Derinlik (cm) } & \multirow{2}{*}{ OM (\%) } & \multicolumn{3}{c}{ Alınabilir $\mathbf{~ ( m g / k g ) ~}$} \\
\cline { 3 - 5 } & & $\mathbf{N O}_{\mathbf{3}}$ & $\mathbf{P}_{\mathbf{2}} \mathbf{O}_{\mathbf{5}}$ & $\mathbf{K}_{\mathbf{2}} \mathbf{O}$ \\
\hline $0-10$ & 1,61 & 22,1 & 17,0 & 307 \\
$10-20$ & 1,44 & 15,0 & 13,1 & 266 \\
$20-30$ & 1,10 & 13,1 & 8,0 & 240 \\
\hline Ortalama (0-30) & 1,38 & 16,7 & 12,7 & 271 \\
\hline
\end{tabular}

Araștırma alanında buharlaşmanın ortalama olarak $1240 \mathrm{~mm}$ düzeylerinde olduğu belirlenmiștir (Maslov, 1984). Yaz aylarındaki buharlaşma miktarı aylık 222-283 mm’ye değin ulaşabilmektedir. Deneme arazisinde yetiştirilen hibrit mısır çeşitlerinden vejetasyon periyodu boyunca gerçekleșen toplam buharlaşma oranını 927-1137 mm civarındadır. Bu değer yağıș toplamının 9-10 katı kadar olup sulama suyuna ihtiyaç duyulduğunu ve düzenli sulama yapılması gerektiğini ortaya koymaktadır.

Kazakistan'da uygun zirai kültürel tedbirlele sulu tarım koşullarında yetiştirilen soya verimi ortalama 5 ton/ha seviyelerine ulaşabilmektedir. Deneme alanı ve bu alanın ekolojik koşullarında Swallow soya çeşidinde verim ortalama 4,65 ton/ha iken Almaty çeşidinde ise 5 ton/ha seviyelerinde belirlenmiştir. Güney Kazakistan'da soya fasülyesi de olmak üzere ürün verimini sınırlandıran en temel faktör özellikle de sonbahar ve kış dönemlerinde yeterli yağıș olmadığında toprak nemidir. Bitkisel ürün verimi üzerine sulamanın önemi kuşkusuzdur. Ancak, sulama sıklığı, toprak-bitki-su ilișkileri, toprakta suyun hareketi gibi hususlarda ise, toprağın fiziksel özellikleri büyük oranda belirleyici rol oynamaktadır (Timiryazev, 1948).

Kültür bitkileri ve mikroorganizmaların gelişim koşulları toprak suyunun fiziksel özelliklerine önemli derecede bağlıdır. Sulu tarımda toprak suyunun fiziksel özellikleri sulama ihtiyacının belirlenmesi ve planlanmasında, toprak işlemede önemli bir yere sahiptir. Deneme arazisinde, $170 \mathrm{~cm}$ 'lik toprak derinliği boyunca bazı toprak fiziksel özellikleri Çizelge 2'de verilmiştir. Toplam porozite, 2018 yllında \%41.5 ile en yüksek \%42,7 (0-10 cm) arasında, 2019 yllında ise yine \%41.7 ile en yüksek \%42,8(0-10 cm) arasında değiştiği saptanmıştır. Toprakların hacim ağırlık değerleri genellikle alt toprak katlarına inildikçe arttığı, benzer durumun özgül ağırlık içinde geçerli olduğu görülmektedir. Toprak suyunun özelliklerine ait temel göstergeler hacimsel ağırlı̆̆ ve en düşük su içeriğidir. Bu özellikler belirlenmeden, sulama norm ve peryotlarının hesaplanması imkansızdır. Higroskopik sabite değerleri ise \% 4,55 - \%4,71 arasında, hacim ağırlığı 1,46 - 1,58 $\mathrm{g} / \mathrm{cm}^{3}$ arasında, toplam porozite $\% 41,5-\% 42,8$ arasında ve toprağın en düşük gravimetrik nem içeriğinin ise \%21,4 - \%22,6 arasında değiștiği saptanmıștır.

Çizelge 2. Toprak profili boyunca toprağın bazı fiziksel özellikleri

\begin{tabular}{|c|c|c|c|c|c|c|c|c|c|c|c|c|c|c|c|}
\hline \multirow{2}{*}{$\begin{array}{l}\text { Derinlik } \\
\text { (cm) }\end{array}$} & \multicolumn{3}{|c|}{ Özgül ağırlık (g/cm³) } & \multicolumn{3}{|c|}{$\begin{array}{c}\text { Higroskopik sabite } \\
(\%)\end{array}$} & \multicolumn{3}{|c|}{$\begin{array}{c}\text { Toplam porozite } \\
(\%)\end{array}$} & \multicolumn{3}{|c|}{$\begin{array}{l}\text { Hacim ağırlığı } \\
\qquad\left(\mathrm{g} / \mathrm{cm}^{3}\right)\end{array}$} & \multicolumn{3}{|c|}{$\begin{array}{c}\text { Toprağın en düşük nem } \\
\text { içeriği (\%) }\end{array}$} \\
\hline & 2018 & 2019 & Ort. & 2018 & 2019 & Ort. & 2018 & 2019 & Ort. & 2018 & 2019 & Ort. & 2018 & 2019 & Ort. \\
\hline $0-10$ & 2,53 & 2,54 & 2,53 & 4,55 & 4,56 & 4,55 & 42,7 & 42,8 & 42,7 & 1,45 & 1,47 & 1,46 & 21,0 & 21,8 & 21,4 \\
\hline $10-20$ & 2,56 & 2,60 & 2,58 & 4,58 & 4,59 & 4,58 & 42,2 & 42,4 & 42,3 & 1,48 & 1,50 & 1,49 & 21,4 & 22,2 & 21,8 \\
\hline $20-30$ & 2,63 & 2,63 & 2,63 & 4,60 & 4,64 & 4,62 & 41,8 & 41,9 & 41,8 & 1,53 & 1,54 & 1,53 & 21,8 & 22,4 & 22,1 \\
\hline $30-40$ & 2,66 & 2,69 & 2,67 & 4,65 & 4,69 & 4,67 & 41,7 & 41,8 & 41,7 & 1,55 & 1,58 & 1,56 & 22,0 & 22,5 & 22,2 \\
\hline $40-50$ & 2,62 & 2,65 & 2,63 & 4,63 & 4,66 & 4,64 & 42,0 & 42,1 & 42,0 & 1,52 & 1,55 & 1,53 & 21,7 & 22,5 & 21,9 \\
\hline $50-60$ & 2,68 & 2,69 & 2,68 & 4,66 & 4,68 & 4,67 & 41,8 & 42,1 & 41,9 & 1,56 & 1,56 & 1,56 & 21,9 & 22,5 & 22,2 \\
\hline $60-70$ & 2,69 & 2,70 & 2,69 & 4,68 & 4,70 & 4,69 & 41,6 & 41,7 & 41,5 & 1,57 & 1,58 & 1,57 & 22,0 & 22,6 & 22,3 \\
\hline $70-80$ & 2,70 & 2,69 & 2,69 & 4,66 & 4,69 & 4,67 & 41,5 & 41,8 & 41,6 & 1,58 & 1,58 & 1,58 & 22,3 & 22,7 & 22,5 \\
\hline $80-90$ & 2,66 & 2,68 & 2,67 & 4,65 & 4,67 & 4,66 & 41,7 & 41,9 & 41,8 & 1,55 & 1,55 & 1,55 & 22,2 & 22,8 & 22,5 \\
\hline $90-100$ & 2,63 & 2,65 & 2,64 & 4,63 & 4,66 & 4,64 & 41,8 & 41,8 & 41,8 & 1,53 & 1,55 & 1,54 & 22,1 & 22,6 & 22,3 \\
\hline $100-170$ & 2,62 & 2,64 & 2,63 & 4,70 & 4,73 & 4,71 & 42,0 & 41,9 & 41,9 & 1,52 & 1,55 & 1,53 & 22,4 & 22,8 & 22,6 \\
\hline $0-50$ & 2,60 & 2,62 & 2,61 & 4,60 & 4,63 & 4,61 & 42,1 & 42,2 & 42,1 & 1,51 & 1,53 & 1,52 & 21,6 & 22,3 & 21,9 \\
\hline $0-60$ & 2,61 & 2,63 & 2,62 & 4,61 & 4,64 & 4,62 & 42,0 & 42,2 & 42,1 & 1,52 & 1,53 & 1,52 & 21,6 & 22,3 & 21,9 \\
\hline $0-70$ & 2,62 & 2,64 & 2,63 & 4,62 & 4,65 & 4,63 & 42,0 & 42,1 & 42,0 & 1,52 & 1,54 & 1,53 & 21,7 & 22,4 & 22,0 \\
\hline $0-100$ & 2,64 & 2,65 & 2,64 & 4,63 & 4,66 & 4,64 & 41,9 & 41,8 & 41,8 & 1,53 & 1,55 & 1,54 & 21,8 & 22,6 & 22,2 \\
\hline $0-170$ & 2,63 & 2,64 & 2,63 & 4,67 & 4,73 & 4,70 & 42,0 & 41,9 & 41,9 & 1,53 & 1,55 & 1,54 & 22,1 & 22,8 & 22,4 \\
\hline
\end{tabular}


Deneme arazisindeki toprakların infiltrasyon değerleri ise Çizelge 3'de verilmiştir. Elde edilen sonuçlara göre, başlangıçta infiltrasyon hızı daha yüksek iken 5.saate değin, infiltrasyon hızlarında kısmende olsa düşmelerin meydana geldiği, 100 mm'lik suyun infiltre olma süresinin 24 saatten daha fazla ve infiltrasyon oranının düşük geçirgenlik sınıfında olduğu saptanmıştır (Dospekhov et al., 1977). Cybulak ve ark. (2016) yaptıkları çalışmada, biochar uygulanan podzolik toprakların maksimum higroskopik nem içeriklerinin çimle kaplı alanlarda yaklaşık \%2.2 ile \%3.3, nadas alanlarda ise \%1.5 ile \%2.5 arasında değiştiğini bildirmişlerdir.

Çizelge 3. Toprakların infiltrasyon oranları

\begin{tabular}{|c|c|c|c|c|c|c|c|c|}
\hline \multirow[t]{2}{*}{ Yll } & \multicolumn{5}{|c|}{ İnfiltrasyon oranı, mm/saat } & \multirow{2}{*}{$\begin{array}{l}\text { 5.satte } \\
\mathrm{m}^{3} / \mathbf{h a}\end{array}$} & \multirow{2}{*}{$\begin{array}{c}\text { Ortalama } \\
\text { infiltrasyon } \\
\mathbf{m}^{3} / \text { ha }\end{array}$} & \multirow{2}{*}{$\begin{array}{c}100 \mathrm{~mm}\left(1000 \mathrm{~m}^{3} / \mathrm{ha}\right) \text { suyun } \\
\text { infiltre olma süresi, } \\
\text { saat }\end{array}$} \\
\hline & 1 saat & 2 saat & 3 saat & 4 saat & 5 saat & & & \\
\hline 201 & 5,34 & 4,20 & 3,78 & 3,60 & 3,42 & 203,4 & 40,7 & 24,6 \\
\hline 2019 & 4,93 & 3,82 & 3,47 & 3,29 & 3,02 & 185,3 & 37,1 & 27,0 \\
\hline
\end{tabular}

\section{Sonuç}

Kazakistan'daki Talas Alatau'nun batısındaki, Tanrı dağlarının eteklerinde bulunan Sierozem topraklarının genellikle lös ve lös benzeri tınlı materyal ile kaplı olduğu ve çok yaygın olamamakla beraber kil depositlerini içerdiği belirlenmiștir. İşlenen yüzey toprakların $(0-30 \mathrm{~cm})$ organik madde içerikleri \%1,38, yarayıșlı fosforun $12.7 \mathrm{mg} / \mathrm{kg}$ ve nitrat azotunun $16.7 \mathrm{mg} / \mathrm{kg}$ ile düşük ve değișebilir K içeriğinin $271 \mathrm{mg} / \mathrm{kg}$ ile orta düzeyde olduğu, belirlenmiştir. Alkalin $\mathrm{pH}$ (7.8) değerine sahip yaygın sierozem toprakların sulama koşularında birçok kültür bitkisinin yetiștirilebileceği sonucuna varılmıștır. Ancak, bölgenin toplam yağış miktarındaki yetersizliklerden dolayı ilave bir sulama yapılmaması durumunda bitkisel ürün veriminden bahsetmek mümkün olmadığı ve ürün verimini artırmak için mutlaka sulama yapılması gerektiği ortaya konulmuştur. Yapılan sulama uygulamalarında ise, geçirgenlik sınıfının yavaş olması nedeniyle $100 \mathrm{~mm}$ !lik sulama suyu uygulanması durumunda ancak 24 saat'ten daha fazla bir sürede (24,6-27 saat) infiltre olabilecektir.

\section{Kaynaklar}

Black CA, 1965. Methods of soil analysis. Part 1 Physical and Mineralogical Methods including statistics of measurement and sampling - Part 2 Chemical and Microbiological Properties. Agronomy Monograph 9.1, American Society of Agronomy and Soil Science Society of America, Madison, Wisconsin, USA.

Burlibayev MJ, Dostai JD, Tursunov AA, 2001. Hydrological problems, water allocation issues: Aralo - Syrdarya pool Almaty, Dauir, p.180.

Cybulak M, Sokolowska Z, Boguta P, 2016. Hygroscopic moisture content of podzolic soil with biochar. Acta Agrophysica, 23(4):533-543.

Didorenko SV, Karyagin YuG, 2006. Soya - the most important grain fodder crop. Bulletin of agricultural sciences of Kazakhstan № 1. p.19-21.

Dmitriev L, 2004. Brief evaluation of IUVRV processes. Implementation of the principles of Integration of Water Resources Management in Central Asia and Caucasus countries - the project of the Regional Technical Advisory Committee of the Global Water Partnership for Central Asia, Caucasus and Kazakhstan, Review Report, Tashkent. p.64-75.

Dospekhov BA, 1977. Field experiment technique. Workshop on Agriculture. Kolos, Moscow, 355p.

Evniev AK, 2005. Role of water sector of the economy and land reclamation in agriculture development. Scientific support as a factor of sustainable water economy development. p.7-10.

Maslov BS, 1984. - Agricultural Land Improvement: Amelioration and Reclamation. Kolos, Moscow, 511p.

Timiryazev KA, 1948. Struggle of plants with drought. Izbr.op., t.2. Oziz-selkhozgiz., 423p.

Tour NS, Zagorulko AA, 1994. Agroecological basics of soybean cultivation: Textbook. Krasnodar, MSAU, p.444.

Zaurbek AK, Makhanov M, 2003. Water utilization system. Taraz University, Taraz, Kazakhstan. 340p. 